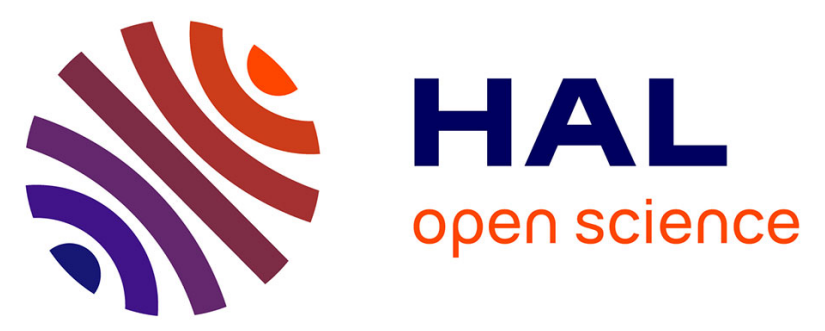

\title{
Effect of body length, trophic position and habitat use on mercury concentrations of sharks from contrasted ecosystems in the southwestern Indian Ocean
}

Baptiste Le Bourg, Jérémy Kiszka, Paco Bustamante, Michael R Heithaus, Sébastien Jaquemet, Frances Humber

\section{To cite this version:}

Baptiste Le Bourg, Jérémy Kiszka, Paco Bustamante, Michael R Heithaus, Sébastien Jaquemet, et al.. Effect of body length, trophic position and habitat use on mercury concentrations of sharks from contrasted ecosystems in the southwestern Indian Ocean. Environmental Research, 2019, 169, pp.387-395. 10.1016/j.envres.2018.11.024 . hal-02343308

\author{
HAL Id: hal-02343308 \\ https://hal.science/hal-02343308
}

Submitted on 2 Nov 2019

HAL is a multi-disciplinary open access archive for the deposit and dissemination of scientific research documents, whether they are published or not. The documents may come from teaching and research institutions in France or abroad, or from public or private research centers.
L'archive ouverte pluridisciplinaire HAL, est destinée au dépôt et à la diffusion de documents scientifiques de niveau recherche, publiés ou non, émanant des établissements d'enseignement et de recherche français ou étrangers, des laboratoires publics ou privés. 
Effect of body length, trophic position and habitat use on mercury concentrations of sharks from contrasted ecosystems in the southwestern Indian Ocean

Baptiste Le Bourg ${ }^{1,2, *}$, Jeremy J. Kiszka ${ }^{3}$, Paco Bustamante ${ }^{1}$, Michael R. Heithaus ${ }^{3}$, Sébastien Jaquemet $^{4}$, Frances Humber ${ }^{5}$

${ }^{1}$ Littoral Environnement et Sociétés (LIENSs), UMR 7266 CNRS-Université de La Rochelle, 2 rue Olympe de Gouges, 17000 La Rochelle, France

${ }^{2}$ Université de Liège, Laboratory of Oceanology, MARE Centre, 4000 Liège, Belgium

${ }^{3}$ Marine Sciences Program, Department of Biological Sciences, Florida International University, 3000 NE 151 Street, FL-33181, North Miami, U.S.A.

${ }^{4}$ UMR Entropie, Université de La Réunion, St Denis, La Réunion, France

${ }^{5}$ Blue Ventures, Level 2 Annex, Omnibus Business Centre, 39-41 North Road, London N7 9DP, United Kingdom.

* Corresponding author at: Université de Liège, Laboratory of Oceanology, MARE Centre, 4000 Liège, Belgium

E-mail adress: baptiste.lebourg@ doct.ulg.ac.be 


\begin{abstract}
The non-essential metal mercury $(\mathrm{Hg})$ can have deleterious effects on health of organisms, and tends to bioaccumulate with age in long-lived organisms and to biomagnify along food chains. Because sharks are fished for human consumption and their $\mathrm{Hg}$ levels are frequently above the maximum $\mathrm{Hg}$ concentration recommended for fish consumption, understanding the drivers of $\mathrm{Hg}$ concentration is of considerable interest. Total $\mathrm{Hg}$ concentrations were analysed in muscle tissues of 14 shark and 2 batoid species ( $\mathrm{n}=339$ individuals) sampled across multiple habitats (coastal, oceanic and bathyal) in the southwestern Indian Ocean. Stable isotope ratios of carbon $\left(\delta^{13} \mathrm{C}\right)$ and nitrogen $\left(\delta^{15} \mathrm{~N}\right)$ were analysed to assess whether relative trophic position and foraging habitats affected $\mathrm{Hg}$ concentrations. $\mathrm{Hg}$ concentrations increased with $\delta^{15} \mathrm{~N}$ and body length, highlighting the mechanisms of bioaccumulation and biomagnification in relation with the trophic position and size of the individuals. Habitats where elasmobranchs were collected also affected their $\mathrm{Hg}$ concentrations. Bathyal sharks had high $\mathrm{Hg}$ concentrations that were almost similar to those of oceanic species, despite their lower relative trophic position. Higher bioavailability of $\mathrm{Hg}$ due to its enhanced methylation in deeper waters was considered as the most likely explanation for this result. These results highlight that multiple factors contribute to mercury accumulation in elasmobranchs.
\end{abstract}

Keywords: Hg, elasmobranchs, stable isotopes, trophic ecology, foraging habitat, body size. 
$-3-$

Funding: The sample analysis of this work was supported by the French grant Contrat de Projet Etat-Région. 


\section{Introduction}

Elasmobranchs are present in many habitats and at various depths. They exhibit a range of foraging strategies and tactics, including planktivorous filter-feeding and predatory species (e.g. Bird et al. 2018; Kiszka and Heithaus 2014). They also have long lifespans (Cortés 1999) and some species grow to large body sizes. Sharks are heavily fished for human consumption (Clarke et al. 2006). However, mercury $(\mathrm{Hg})$ concentrations reported in sharks are frequently above the maximum values recommended for fish consumption $\left(1 \mu \mathrm{g} . \mathrm{g}^{-1}\right.$ wet weight; Escobar-Sánchez et al. 2011; Hueter et al. 1995; Kousteni et al. 2006; McKinney et al. 2016). Hg is toxic to organisms at low concentrations with known sublethal effects including reduced growth, impacts on reproduction (e.g. reduced fertility and spawning success), abnormal behaviour (e.g. increased lethargy) and tissue damages (Depew et al. 2012; Díez 2008; Sandheinrich and Wiener 2011). Hg is released in the environment by both natural and anthropogenic sources (Fitzgerald et al. 2007; Selin 2009). It is known to be present in aquatic organisms mainly in the form of highly toxic methylmercury $\left(\mathrm{CH}_{3} \mathrm{Hg}\right)$ form (Bloom 1992; Jones et al. 2013; Pethybridge et al. 2010; Storelli et al. 2002; 2003). Due to its high assimilation rate and affinity for proteins, $\mathrm{CH}_{3} \mathrm{Hg}$ bioaccumulates in organisms through time and biomagnifies up food webs (Atwell et al. 1998; Mason et al. 1995; Power et al. 2002).

Various biological and ecological factors influence $\mathrm{Hg}$ concentrations in aquatic animals including elasmobranchs. Body length (a proxy for animal size) and age may be considered as the main factors determining $\mathrm{Hg}$ concentrations. $\mathrm{Hg}$ concentrations increase with size in various taxa such as cephalopods (e.g. Chouvelon et al. 2011), predatory teleosts (Cresson et al. 2014; Kojadinovic et al. 2006; Sackett et al. 2013) and elasmobranchs (Cresson et al. 2014; Hueter et al. 1995; McKinney et al. 2016; Pethybridge et al. 2010; 2012; Rumbold et al. 2014). Differences in life-history traits may also influence $\mathrm{Hg}$ dynamics in elasmobranchs (e.g. Le Bourg et al. 2014; Lyons and Lowe 2013; Pethybridge et al. 2010). Relationships between trophic position metrics and $\mathrm{Hg}$ concentrations at 
the levels of species (Cresson et al. 2014; Pethybridge et al. 2012), taxonomic groups (McKinney et al. 2016; Pethybridge et al. 2012) and communities (Atwell et al. 1998; Campbell et al. 2008; Lavoie et al. 2010; Power et al. 2002) show that feeding ecology of organisms dramatically influences $\mathrm{Hg}$ concentrations. Spatial variations of $\mathrm{Hg}$ concentrations in organisms (Hisamichi et al. 2010; Jones et al. 2013; Kojadinovic et al. 2006; Sackett et al. 2013) or correlations between depth of occurrence appears to be particularly important in driving $\mathrm{Hg}$ concentrations (Blum et al. 2013; Chouvelon et al. 2012; Choy et al. 2009; Monteiro et al. 1996), but the relative importance of environmental drivers on $\mathrm{Hg}$ concentrations in marine predators is still relatively poorly understood. Furthermore, $\mathrm{Hg}$ concentrations are poorly documented for a number of ocean regions such as in the western Indian Ocean (but see Chouvelon et al. 2017; McKinney et al. 2016; Kojadinovic et al. 2006).

The aim of this study was to investigate the effects of body size, trophic position, and broad habitat characteristics on $\mathrm{Hg}$ concentrations in sharks and other elasmobranchs of the south-western Indian Ocean (coastal, open ocean and bathyal). We used stable isotope ratios of carbon $\left({ }^{13} \mathrm{C}:{ }^{12} \mathrm{C}\right.$, denoted $\left.\delta^{13} \mathrm{C}\right)$ and nitrogen $\left({ }^{15} \mathrm{~N}:{ }^{14} \mathrm{~N}\right.$, denoted $\left.\delta^{15} \mathrm{~N}\right)$ to respectively assess the effect of foraging habitat and trophic positions on observed Hg concentrations (Hobson 1999; Michener and Kaufman 2007). Increasing $\mathrm{Hg}$ concentrations with body length because of bioaccumulation and with $\delta^{15} \mathrm{~N}$ because of bioamplification are expected. Furthermore, high $\mathrm{Hg}$ concentrations are expected in sharks from the deep sea because of the enhanced methylation processes in the deep-sea waters (Blum et al. 2013).

\section{Material and methods}

\subsection{Sampling and samples preparation}

White muscle samples were collected from the dorsal region of 14 shark and 2 batoid species in the south-western Indian Ocean from three sampling locations: southwestern Madagascar, La Réunion 
Island and the oceanic waters of the southwestern Indian Ocean, from southern Madagascar to the Mascarene archipelago (between $43^{\circ} 30^{\prime} \mathrm{E}$ and $70^{\circ} 00^{\prime} \mathrm{E}$ and $16^{\circ} 30^{\prime} \mathrm{S}$ and $28^{\circ} 30^{\prime} \mathrm{S}$ ). Elasmobranchs sampled in Madagascar were caught between April 2009 and May 2010 by traditional fishers (non-motorised boats) with gillnets and longlines and brought back to five landing sites where local data collectors took elasmobranch muscle samples for stable isotope and $\mathrm{Hg}$ analysis. Details on sampling in Madagascar are provided in Kiszka et al. (2014). Elasmobranchs of the oceanic waters of the region were sampled during scientific longline fishing cruises or by observers on commercial longline fishing vessels from January 2009 to November 2010. Details on sampling locations in the open ocean are available in Kiszka et al. (2015). Bathyal sharks and bull sharks (Carcharhinus leucas) of La Réunion were caught in November 2011 and between June and July 2013, respectively, using longlines and drumlines. For all individuals, species, sex and basic morphometric measurements, including total and fork lengths were recorded and muscle samples were collected and frozen at $-20^{\circ} \mathrm{C}$ until further processing. A total of 339 samples were collected. Each species was assigned to a preferred habitat (coastal, open ocean and bathyal) according to ecological characteristics indicated in the literature and the location where it was captured (Table A.1). Most scalloped hammerheads (Sphyrna lewini) were juveniles and were caught in the coastal waters of Madagascar (Humber et al. 2017). Therefore, although adult scalloped hammerhead sharks tend to be oceanic, those in this study were considered coastal (Compagno et al. 1984b; Hussey et al. 2011; Kiszka et al. 2014). In the laboratory, samples were freeze-dried and then grounded into a homogenous powder using a porcelain mortar and a pestle previously decontaminated in an acid bath.

\subsection{Stable isotope analyses}

Subsamples of homogenised elasmobranch muscles were repeatedly (2 to 3 treatments) shaken for one hour in $4 \mathrm{ml}$ of cyclohexane in order to remove lipids, which can affect $\delta^{13} \mathrm{C}$ values, and trimethyl-amine oxide (TMAO), which can affect $\delta^{15} \mathrm{~N}$ values (Hussey et al. 2012). They were then 
centrifuged for $5 \mathrm{~min}$ at $4000 \mathrm{~g}$, and the supernatant containing lipids was discarded. Lipid-free subsamples $(0.35-0.45 \mathrm{mg})$ were dried and then then weighted in tin cups and analysed with a continuous flow isotope-ratio mass spectrometer (Delta V Advantage, Thermo Scientific) coupled to an elemental analyser (Flash EA 1112, Thermo Scientific). Reference gas was calibrated against International Reference Materials (IAEA-N1, IAEA-N2 and IAEA-N3 for nitrogen; NBS-21, USGS-24 and IAEA-C6 for carbon). Results are expressed in \%o in the $\delta$ notation relative to PeeDee Belemnite and atmospheric $\mathrm{N}_{2}$ for $\delta^{13} \mathrm{C}$ and $\delta^{15} \mathrm{~N}$, according to the equation: $\delta \mathrm{X}=\left[\left(\mathrm{R}_{\text {sample }} /\right.\right.$ $\left.\left.\mathrm{R}_{\text {standard }}\right)-1\right] \times 10^{3}$, where $\mathrm{X}$ is ${ }^{13} \mathrm{C}$ or ${ }^{15} \mathrm{~N}$ and $\mathrm{R}$ is the isotope ratio ${ }^{13} \mathrm{C}:{ }^{12} \mathrm{C}$ or ${ }^{15} \mathrm{~N}:{ }^{14} \mathrm{~N}$. Percent $\mathrm{C}$ and $\mathrm{N}$ elemental composition of tissues were obtained using the elemental analyser and the calculated C:N ratios were always below 3.5, indicating good lipid removal efficiency.

Trophic position (TP) was calculated for elasmobranchs (except the spinetail devil ray Mobula japanica) according to Hussey et al. (2014a; 2014b) and the baseline values used in Kiszka et al. (2015):

$$
T P=\frac{\log \left(\delta^{15} N_{\lim }-\delta^{15} N_{\text {base }}\right)-\log \left(\delta^{15} N_{\text {lim }}-\delta^{15} N_{T P}\right)}{k}+T P_{\text {base }}
$$

$\delta^{15} \mathrm{~N}_{\text {base }}$ and $\mathrm{TP}_{\text {base }}$ are the known $\delta^{15} \mathrm{~N}$ value and TP of a consumer (9.7 and 3, respectively). Here, the values are based on four individuals of the species Mobula mobular (planktivorous) whose mean $\pm \mathrm{SD} \delta^{15} \mathrm{~N}$ values in white muscle were $9.7 \pm 0.1 \%$. $\delta^{15} \mathrm{~N}_{\mathrm{TP}}$ is the $\delta^{15} \mathrm{~N}$ value of the consumer of interest. $\delta^{15} \mathrm{~N}_{\text {lim }}$ is the $\delta^{15} \mathrm{~N}$ value at which ${ }^{15} \mathrm{~N}$ incorporation and ${ }^{15} \mathrm{~N}$ elimination are equal (21.9). $\mathrm{k}$ is the averaged rate at which the ratio between ${ }^{15} \mathrm{~N}$ incorporation and ${ }^{15} \mathrm{~N}$ elimination changes relative to dietary $\delta^{15} \mathrm{~N}$ averaged across the food web (0.14). 


\subsection{Hg analyses}

Total Hg measurements were calculated using a solid sample atomic absorption spectrometer AMA254 (Advanced Mercury Analyser-254; Altec®), except for the bull shark samples from La Réunion Island. At least two aliquots of 5-15 mg of homogenised dry muscle subsamples for each individual were analysed. The analytical quality (i.e. accuracy and reproducibility) of the $\mathrm{Hg}$ measurements by the AMA-254 was assessed by the analyses of blanks and certified reference material (CRM) TORT-2 (Lobster Hepatopancreas from the National Research Council of Canada; www.nrccnrc.gc.ca; certified $\mathrm{Hg}$ concentration: $0.27 \pm 0.06 \mu \mathrm{g} \cdot \mathrm{g}^{-1} \mathrm{dw}$ ) at the beginning and at the end of the analytical cycle, and by running controls for every 10 samples (Bustamante et al. 2006). Measured values were $0.26 \pm 0.02 \mu \mathrm{g} \cdot \mathrm{g}^{-1}$ dry weight $(\mathrm{dw}), \mathrm{n}=20$. Mass of the $\mathrm{CRM}$ was adjusted to represent an amount of $\mathrm{Hg}$ similar to that in muscle samples. Blanks were analysed at the beginning of each set of samples and the limit of detection was $0.005 \mu \mathrm{g} \cdot \mathrm{g}^{-1} \mathrm{dw}$. For bull sharks, $\mathrm{Hg}$ concentrations were measured from proton-induced X-ray emission (PIXE) analyses at GNS Sciences, New Zealand. Hg concentrations in tissues reported are expressed in $\mu \mathrm{g} \cdot \mathrm{g}^{-1} \mathrm{dw}$ but can be converted to wet weight by using a factor of 5 corresponding to an average $80 \%$ moisture (Cresson et al. 2014) to compare our results with previously published ones.

\subsection{Statistical analysis}

$\mathrm{Hg}$ concentrations were $\log (\mathrm{x}+1)$-transformed (indicated as log-transformed in the following) to obtain a normal distribution of the data. As the maximum length differs between shark species and habitat, fork length values were standardised between 0 (juveniles) and 1 (adults) by dividing them by a theoretical maximum fork length for each species. The theoretical maximum fork length $\mathrm{FL}_{\max }$ was estimated by using the following fork length-total length relationship:

$$
F L_{\max }=a \times T L_{\max }+b
$$


with $T L_{\max }$ being the maximum total length reported for each species as the total length value and $a$ and $b$ being species specific constants (Binohlan et al. 2011; Kohler et al. 1996; table A.1). In several species, the standardised length of the largest individuals may be higher than 1 if using the highest total length reported. Consequently, the standardisation was done by dividing fork length values by the maximum fork length value we measured for these species. Furthermore, as both species of spurdog (Squalus spp.) were not precisely identified, the standardisation of fork length for these sharks was done by dividing fork length values by a same maximum fork length value we got for both species combined (Table A.1).

Relationships between the continuous variables (log-transformed $\mathrm{Hg}$ concentrations, standardised fork length, $\delta^{13} \mathrm{C}$ and $\delta^{15} \mathrm{~N}$ values) were preliminary investigated with a principal component analysis (PCA). Because the sampling was concentrated on restricted areas for coastal and bathyal elasmobranchs, latitude and longitude were not included in the PCA. However, because open ocean elasmobranchs have a broad distribution, the relationship between log-transformed $\mathrm{Hg}$ concentrations and longitude of sampling was investigated for this group. A general linear model (GLM) followed by type III analysis of covariance (ANCOVA, F) was performed to assess the influence of standardised fork length, $\delta^{15} \mathrm{~N}$ values and the habitat (either coastal/inshore, open ocean and bathyal) on log-transformed $\mathrm{Hg}$ concentrations. Second order interactions and non-significant first order interactions were progressively removed from the model and a post-hoc Scheffe analysis was performed on the habitat factor. Species with low sample size $(n<5)$ were not included in the model. For each habitat, the influence of standardised fork length, $\delta^{15} \mathrm{~N}$ values and species on $\log$ transformed Hg concentrations were then assessed with GLM followed by type III ANCOVAs. Sex was not included in the models because no significant effects were observed in a first preliminary ANCOVA from which were removed five unsexed individuals and the pelagic thresher shark Alopias pelagicus for which only males were sampled. Pearson correlation coefficients between log-transformed $\mathrm{Hg}$ concentrations and standardised fork length were computed for each species, excepting those with $n<10$ individuals. The same analysis was done to study the relationship of 
log-transformed $\mathrm{Hg}$ concentrations with $\delta^{15} \mathrm{~N}$ and $\delta^{13} \mathrm{C}$ values. All analyses were performed using $\mathrm{R}$ 3.3.3 (R development Core Team).

\section{Results}

\subsection{Factors influencing Hg concentration differences between habitats}

The PCA performed on $\mathrm{Hg}$ concentration, standardised size of the individuals, $\delta^{15} \mathrm{~N}$ and $\delta^{13} \mathrm{C}$ values explained almost $70 \%$ of the variance of the data set with the two first axes. Results of the PCA showed that $\mathrm{Hg}$ concentrations were positively and strongly correlated to $\delta^{15} \mathrm{~N}$ (proxy of trophic level) and negatively correlated to $\delta^{13} \mathrm{C}$ values (Fig. 1a). This suggested a potential effect of habitat on $\mathrm{Hg}$ concentrations, with habitats segregating along the first axis (Fig. $1 \mathrm{~b}$ and A.1). Oceanic individuals had higher $\mathrm{Hg}$ concentrations and higher relative $\delta^{15} \mathrm{~N}$ values. Coastal and bathyal elasmobranchs had lower $\mathrm{Hg}$ concentrations and lower $\delta^{15} \mathrm{~N}$ values (Table 1).

No relationship between $\mathrm{Hg}$ concentrations and longitude was observed for oceanic sharks $(\mathrm{r}=$ $0.051, \mathrm{P}=0.625 ;$ Fig. A.2).

a)

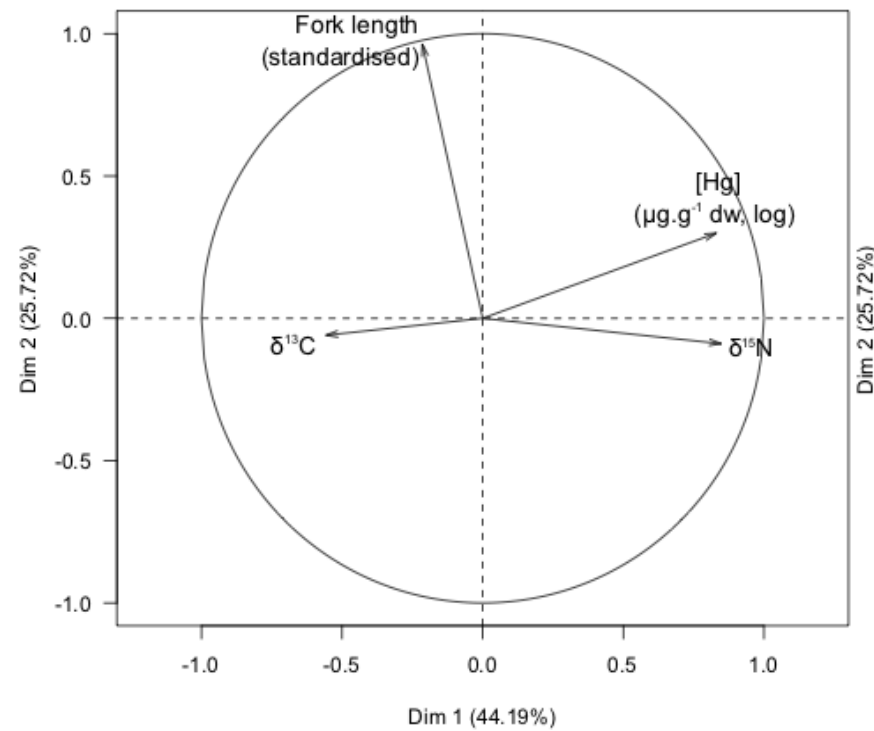

b)

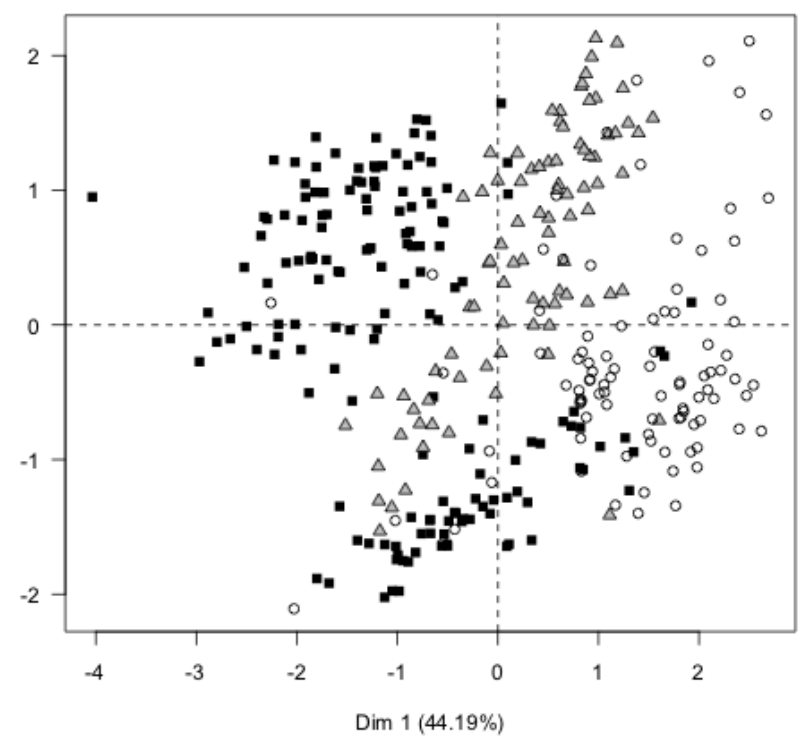

Fig. 1. Results of PCA: a) correlations between log-transformed $\mathrm{Hg}$ concentrations $\left(\mu \mathrm{g} \cdot \mathrm{g}^{-1} \mathrm{dw}\right)$, standardised fork length, $\delta^{15} \mathrm{~N}$ and $\delta^{13} \mathrm{C}$ values (\%o). b) plot of the individuals resulting from the PCA with symbols indicating the habitat: black squares: coastal, white points: open ocean, grey 
triangles: bathyal. For a more detailed plot, see Fig. A.1.

Table 1. Length ranges, mean $\pm \mathrm{SD}$ stable isotope values, $\mathrm{Hg}$ concentrations and trophic positions of elasmobranchs sampled in south-western Indian Ocean.

\begin{tabular}{|c|c|c|c|c|c|c|c|}
\hline & Abbreviation & $\mathrm{n}$ & Fork length range $(\mathrm{cm})$ & $\delta^{15} \mathrm{~N}(\% 0)$ & $\delta^{13} \mathrm{C}(\%)$ & $\mathrm{Hg}\left(\mu \mathrm{g} \cdot \mathrm{g}^{-1} \mathrm{dw}\right)$ & TP \\
\hline Coastal & & 157 & $58.0-325.0$ & $12.0 \pm 0.9$ & $-15.5 \pm 1.0$ & $1.95 \pm 1.58$ & $3.68 \pm 0.31$ \\
\hline Carcharhinus leucas & Cleu & 11 & $214.0-325.0$ & $12.6 \pm 0.6$ & $-15.5 \pm 0.7$ & $2.18 \pm 1.46$ & $3.86 \pm 0.21$ \\
\hline Loxodon macrorhinus & Lm & 83 & $62.0-100.0$ & $11.7 \pm 0.6$ & $-15.4 \pm 1.0$ & $1.25 \pm 0.96$ & $3.55 \pm 0.18$ \\
\hline Rhynchobatus djiddensis & $\mathrm{Rd}$ & 19 & $65.0-190.0$ & $11.9 \pm 0.4$ & $-14.7 \pm 0.4$ & $3.07 \pm 1.20$ & $3.63 \pm 0.13$ \\
\hline Sphyrna lewini & $\mathrm{SI}$ & 44 & $58.0-190.0$ & $12.7 \pm 1.2$ & $-15.9 \pm 1.1$ & $2.74 \pm 2.01$ & $3.90 \pm 0.43$ \\
\hline Open ocean & & 94 & $73.0-304.0$ & $13.8 \pm 1.2$ & $-16.8 \pm 1.0$ & $6.49 \pm 5.15$ & $4.30 \pm 0.44$ \\
\hline Alopias pelagicus & $\mathrm{Ap}$ & 5 & $147.0-268.0$ & $13.9 \pm 0.7$ & $-16.7 \pm 0.4$ & $4.97 \pm 3.57$ & $4.32 \pm 0.26$ \\
\hline Carcharhinus falciformis & $\mathrm{Cf}$ & 10 & $73.0-260.0$ & $12.7 \pm 1.2$ & $-15.0 \pm 1.4$ & $7.13 \pm 7.20$ & $3.91 \pm 0.42$ \\
\hline Carcharhinus longimanus & Clon & 13 & $99.0-229.0$ & $13.4 \pm 1.1$ & $-16.5 \pm 0.5$ & $7.41 \pm 7.91$ & $4.14 \pm 0.38$ \\
\hline Isurus oxyrinchus & lo & 29 & $122.0-304.0$ & $14.6 \pm 0.7$ & $-16.7 \pm 0.6$ & $5.96 \pm 2.78$ & $4.62 \pm 0.29$ \\
\hline Mobula sp. & Mj & 1 & 221 & 9,7 & $-17,4$ & 0,14 & NA \\
\hline Prionace glauca & $\mathrm{Pg}$ & 31 & $160.0-269.0$ & $13.6 \pm 1.1$ & $-17.5 \pm 0.5$ & $5.11 \pm 1.88$ & $4.21 \pm 0.42$ \\
\hline Pseudocarcharias kamoharai & $\mathrm{Pk}$ & 5 & $82.0-95.0$ & $14.3 \pm 0.6$ & $-16.6 \pm 0.1$ & $17.25 \pm 6.45$ & $4.49 \pm 0.24$ \\
\hline Bathyal & & 88 & $26.0-120.0$ & $12.3 \pm 0.6$ & $-16.9 \pm 0.2$ & $5.59 \pm 3.76$ & $3.74 \pm 0.20$ \\
\hline Centrophorus moluccensis & $\mathrm{Cm}$ & 16 & $29.0-77.5$ & $12.0 \pm 0.5$ & $-16.7 \pm 0.4$ & $3.35 \pm 2.18$ & $3.65 \pm 0.15$ \\
\hline Hexanchus nakamurai & $\mathrm{Hn}$ & 1 & 120 & 12,8 & $-16,1$ & 5,22 & 3,92 \\
\hline Squalus sp. 1 & Ssp 1 & 57 & $26.0-69.5$ & $12.3 \pm 0.6$ & $-16.9 \pm 0.1$ & $6.25 \pm 3.92$ & $3.74 \pm 0.17$ \\
\hline Squalus sp. 2 & Ssp 2 & 12 & $31.0-64.0$ & $12.2 \pm 0.6$ & $-16.9 \pm 0.2$ & $5.75 \pm 4.02$ & $3.71 \pm 0.20$ \\
\hline Zameus squamulosus & Zs & 2 & $25.7-29.8$ & $14.3 \pm 0.4$ & $-16.8 \pm 0.2$ & $4.06 \pm 3.53$ & $4.46 \pm 0.18$ \\
\hline
\end{tabular}

The GLM and subsequent ANCOVA results (Table 2) supported PCA results, with Hg concentrations increasing with $\delta^{15} \mathrm{~N}$ values and varying with habitat. Open ocean elasmobranchs had the highest $\mathrm{Hg}$ concentrations, closely followed by bathyal species. In contrast, coastal elasmobranchs had the lowest $\mathrm{Hg}$ concentrations recorded (Fig. 2a; Table 1). Influence of standardised fork length, as well as its interaction with the habitat, on $\mathrm{Hg}$ concentrations were also observed. The interaction between habitat and fork length showed that an increase of $\mathrm{Hg}$ concentrations with standardised size occurred in open ocean and bathyal sharks but that $\mathrm{Hg}$ concentrations decreased with standardised size in coastal species (Fig. 3 and A.3). This decrease occurred because most of the elasmobranchs with the highest standardised length were sliteye sharks (Loxodon macrorhinus) which also have the lowest $\mathrm{Hg}$ concentrations in the coastal habitat (see section 3.2). 
a)

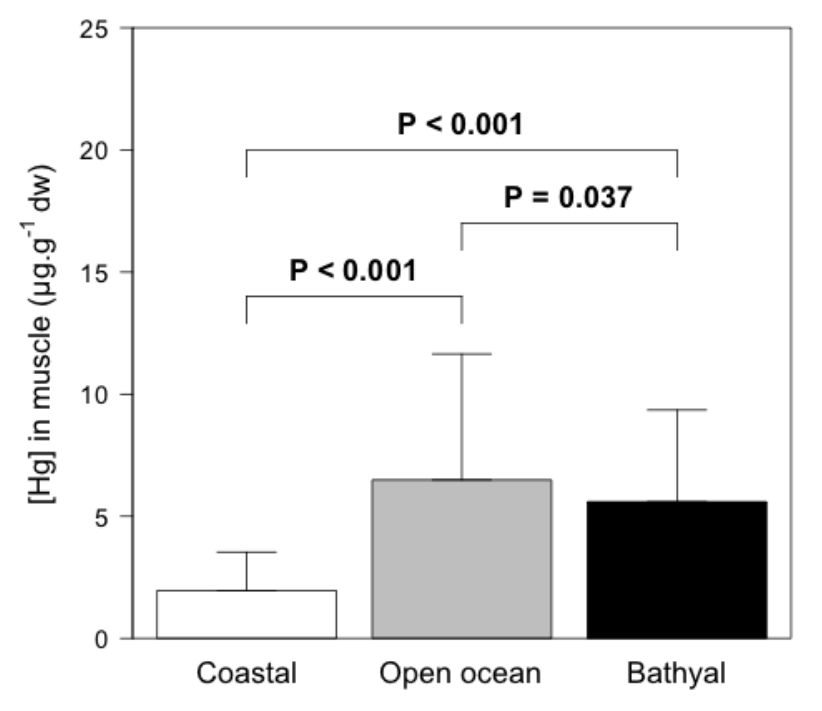

b)

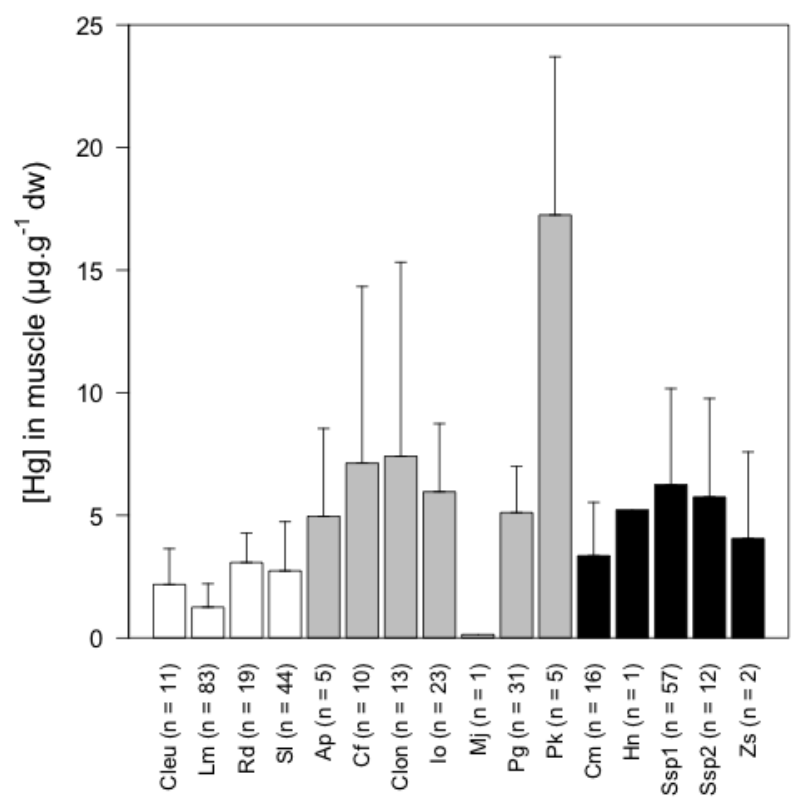

Fig. 2. $\mathrm{Hg}$ concentrations $\left(\mu \mathrm{g} \cdot \mathrm{g}^{-1} \mathrm{dw}\right.$, mean $\left.+\mathrm{SD}\right)$ in muscle of elasmobranchs by a) preferred habitat and b) by species (Cleu: Carcharhinus leucas, Lm: Loxodon macrorhinus, Rd: Rhynchobatus djiddensis, Sl: Sphyrna lewini, Ap: Alopias pelagicus, Cf: Carcharhinus falciformis, Clon: Carcharhinus longimanus, Io: Isurus oxyrinchus, Mj: Mobula japanica, Pg: Prionace glauca, Pk: Pseudocarcharias kamohrai, Cm: Centrophorus moluccensis, Hn: Hexanchus nakamurai, Ssp1: Squalus sp. 1, Ssp2: Squalus sp. 2, Zs: Zameus squamulosus). White: coastal, grey: open ocean, black: bathyal. P values are the results of the post-hoc Scheffe analysis on the habitat factor. 


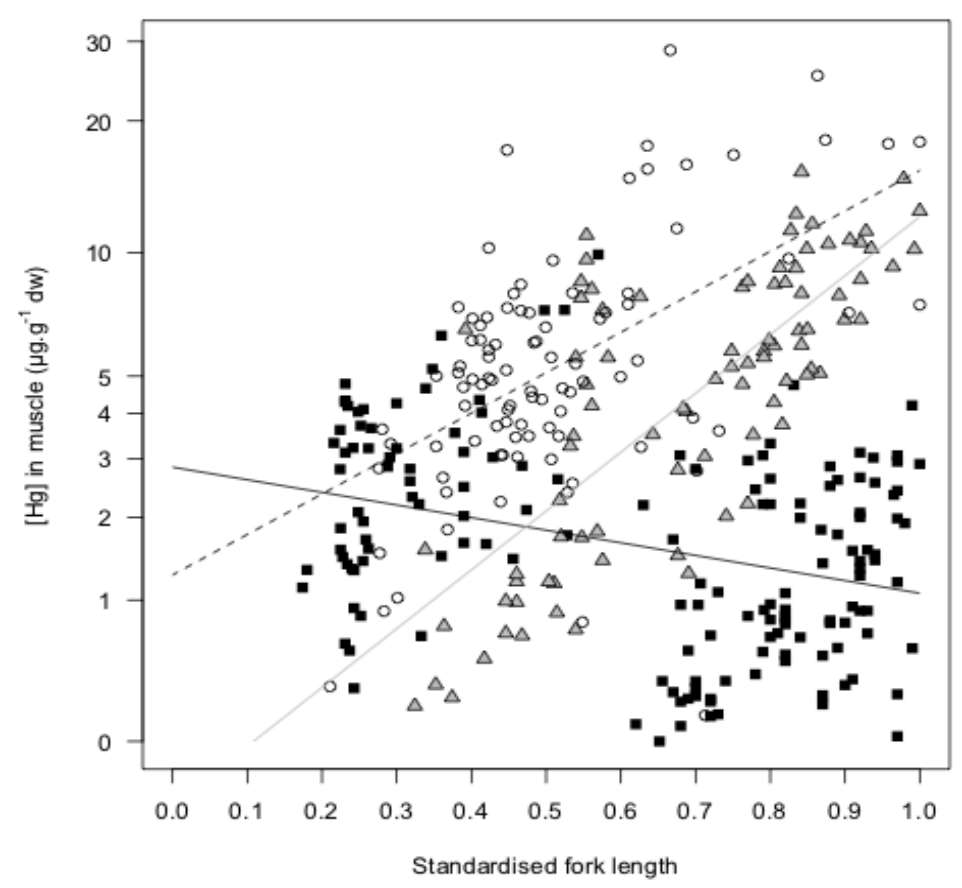

Fig. 3. Relationship between the standardised fork length and $\mathrm{Hg}$ concentrations $(\log (\mathrm{x}+1)$-scale, $\mu \mathrm{g} \cdot \mathrm{g}^{-1} \mathrm{dw}$ ) in muscle of elasmobranchs with symbols and lines indicating the habitat: black squares and black line: coastal; white points and dashed line: open ocean; grey triangles and grey line: bathyal. For a more detailed plot, see Fig. A.3. 
Table 2. Effects of standardised fork length, $\delta^{15} \mathrm{~N}$ values, habitat and species of elasmobranch on $\log$-transformed $\mathrm{Hg}$ concentrations. Bold results are significant at the $\mathrm{P}=0.05$ level.

\begin{tabular}{|c|c|c|c|}
\hline & $\mathrm{df}$ & $\mathrm{F}$ & $\mathrm{P}$ \\
\hline \multicolumn{4}{|l|}{$\overline{\mathrm{All}}$} \\
\hline Standardised fork length & 1,328 & 106.269 & $<0.001$ \\
\hline$\delta^{15} \mathrm{~N}(\%)$ & 1,328 & 71.382 & $<0.001$ \\
\hline Habitat & 2,328 & 28.243 & $<0.001$ \\
\hline Standardised fork length : Habitat & 2,328 & 69.645 & $<0.001$ \\
\hline \multicolumn{4}{|l|}{ Coastal } \\
\hline Standardised fork length & 1,145 & 9.468 & 0.003 \\
\hline$\delta^{15} \mathrm{~N}(\%)$ & 1,145 & 1.406 & 0.238 \\
\hline Species & 3,145 & 8.057 & $<0.001$ \\
\hline Standardised fork length: Species & 3,145 & 9.670 & $<0.001$ \\
\hline$\delta^{15} N(\%):$ Species & 3,145 & 5.499 & 0.001 \\
\hline \multicolumn{4}{|l|}{ Open ocean } \\
\hline Standardised fork length & 1,80 & 67.469 & $<0.001$ \\
\hline$\delta^{15} \mathrm{~N}(\%)$ & 1,80 & 3.216 & 0.077 \\
\hline Species & 5,80 & 3.034 & 0.015 \\
\hline$\delta^{15} \mathrm{~N}(\% 0):$ Species & 5,80 & 3.352 & 0.008 \\
\hline \multicolumn{4}{|l|}{ Bathyal } \\
\hline Standardised fork length & 1,80 & 34.203 & $<0.001$ \\
\hline$\delta^{15} \mathrm{~N}(\%)$ & 1,80 & 9.920 & 0.002 \\
\hline Species & 2,80 & 1.703 & 0.189 \\
\hline
\end{tabular}

\subsection{Factors influencing Hg concentrations within habitats}

Within each habitat, $\mathrm{Hg}$ concentrations were influenced by standardised size thanks to the significant correlations between the standardised size and $\mathrm{Hg}$ concentrations within all species (tables 2 and 3). Variation in $\mathrm{Hg}$ concentrations amongst species occurred in the coastal habitat, with the sliteye shark (L. macrorhinus) having lower Hg concentrations $\left(1.25 \pm 0.96 \mu \mathrm{g} . \mathrm{g}^{-1} \mathrm{dw}\right)$ than the other species, and in the open ocean habitat, with the crocodile shark (Pseudocarcharias kamoharai) having much higher $\mathrm{Hg}$ concentrations $\left(17.25 \pm 6.45 \mu \mathrm{g} . \mathrm{g}^{-1} \mathrm{dw}\right)$ than the other species, but not in the bathyal habitat (Fig. 2b; Tables 2 and 3). The interaction between species and standardised size also influenced $\mathrm{Hg}$ concentrations in the coastal habitat thanks to the negative correlation between the standardised size and $\mathrm{Hg}$ concentrations observed in the giant guitarfish 
(Rhynchobatus djiddensis). $\mathrm{Hg}$ concentrations increased with $\delta^{15} \mathrm{~N}$ values in bathyal sharks only but the interaction between the species and $\delta^{15} \mathrm{~N}$ values influenced $\mathrm{Hg}$ concentrations in coastal and open ocean elasmobranchs (Table 2). The significant and positive correlation between $\delta^{15} \mathrm{~N}$ values and $\mathrm{Hg}$ concentrations within all bathyal species and the lack of correlation for several coastal and open ocean species (Carcharhinus leucas, Carcharhinus longimanus, Isurus oxyrinchus and $R$. djiddensis; Table 3) may explain this pattern.

Lastly, a significant positive correlation between $\mathrm{Hg}$ concentrations and $\delta^{13} \mathrm{C}$ values appeared only in the pelagic silky sharks (Carcharhinus falciformis) and blue sharks (Prionace glauca) and in the bathyal Centrophorus moluccensis and Squalus sp. 1 (Table 3), maybe as the result of ontogenetic change in foraging habitat in these species.

In a few cases, the correlations in Table 3 were not highly significant (or even not significant, if a Bonferroni correction was applied), but this does not modify these conclusions.

Table 3. Results of Pearson correlation tests between log-transformed $\mathrm{Hg}$ concentrations in elasmobranch muscles and standardised fork length, $\delta^{15} \mathrm{~N}$ values and $\delta^{13} \mathrm{C}$ values. Bold results are significant at the $\mathrm{P}=0.05$ level. Italic results are no more significant if applying Bonferroni correction, when the $0.05 \mathrm{P}$-level is divided by the number of tests (33 tests and $\mathrm{P}=0.0015$, Rice 1989).

\begin{tabular}{|c|c|c|c|c|c|c|c|c|c|}
\hline & \multicolumn{3}{|c|}{$\begin{array}{l}\text { Standardised } \\
\text { fork length }\end{array}$} & \multicolumn{3}{|c|}{$\delta^{15} \mathrm{~N}$} & \multicolumn{3}{|c|}{$\delta^{13} \mathrm{C}$} \\
\hline & $\mathrm{df}$ & $r$ & $\mathrm{P}$ & $\overline{d f}$ & $r$ & $\mathrm{P}$ & $\mathrm{df}$ & $r$ & $\mathrm{P}$ \\
\hline \multicolumn{10}{|l|}{ Coastal } \\
\hline Carcharhinus leucas $(\mathrm{n}=11)$ & 9 & 0.612 & 0.045 & 9 & 0.010 & 0.976 & 9 & -0.562 & 0.072 \\
\hline Loxodon macrorhinus $(\mathrm{n}=83)$ & 81 & 0.379 & $<0.001$ & 81 & 0.517 & $<0.001$ & 81 & 0.059 & 0.598 \\
\hline Rhynchoba & 17 & -0.758 & $<0.001$ & 17 & 0.313 & 0.192 & 17 & -0.096 & 0.696 \\
\hline Sphyrna lewini $(n=44)$ & 42 & 0.625 & $<0.001$ & 42 & 0.495 & $<0.001$ & 42 & -0.011 & 0.941 \\
\hline \multicolumn{10}{|l|}{ Open ocean } \\
\hline Carcharhinus fal & 8 & 0.662 & 0.037 & 8 & 0.669 & 0.034 & 8 & 0.692 & 0.027 \\
\hline Carcl & 11 & 0.756 & 0.003 & 11 & 0.453 & 0.120 & 11 & -0.128 & 0.677 \\
\hline Isuru & 27 & 0.630 & $<0.001$ & 27 & 0.064 & 0.742 & 27 & 0.072 & 0.709 \\
\hline Prionace glauca $(\mathrm{n}=31)$ & 29 & 0.675 & $<0.001$ & 29 & 0.638 & $<0.001$ & 29 & 0.697 & $<0.001$ \\
\hline \multicolumn{10}{|l|}{ Bathyal } \\
\hline Centrophorus moluccensi & 14 & 0.941 & $<0.001$ & 14 & 0.642 & 0.007 & 14 & 0.762 & $<0.001$ \\
\hline Squalus sp. $1(\mathrm{n}=57)$ & 55 & 0.723 & $<0.001$ & 55 & 0.667 & $<0.001$ & 55 & 0.641 & $<0.001$ \\
\hline Squalus sp. $2(\mathrm{n}=12)$ & 10 & 0.808 & 0.001 & 10 & 0.881 & $<0.001$ & 10 & 0.157 & 0.626 \\
\hline
\end{tabular}




\section{Discussion}

In this study, the influence of various factors on $\mathrm{Hg}$ concentrations in elasmobranchs from Indian Ocean was assessed. Foraging habitat, body length and trophic level appeared to contribute significantly to the bioaccumulation of $\mathrm{Hg}$ in elasmobranchs.

With the exception of the crocodile shark (P. kamoharai), mean $\mathrm{Hg}$ concentrations reported in elasmobranch muscles in this study were lower than those reported for sharks sampled off eastern South Africa (McKinney et al. 2016). By contrast, lower $\mathrm{Hg}$ concentrations were reported in western South Africa than in the waters between La Réunion and Madagascar in albacore tuna Thunnus alalunga (Chouvelon et al. 2017). Thus, local factors may explain variation in $\mathrm{Hg}$ concentrations between regions. For coastal sharks, $\mathrm{Hg}$ concentrations reported in bull sharks $(C$. leucas) were two to four times lower than those reported near South Africa (McKinney et al. 2016) and off Florida (Adams and McMichael 1999; Hueter et al. 1995; Rumbold et al. 2014). For open ocean sharks, $\mathrm{Hg}$ concentrations reported in mako sharks (I. Oxyrinchus) were three times lower than those reported near South Africa (McKinney et al. 2016) but higher than those reported in Mexican Pacific waters (Escobar-Sánchez et al. 2011; Maz-Courrau et al. 2012) and in the Atlantic Ocean (Biton Porsmoguer et al. 2018). Similarly, higher Hg concentrations were reported in our study than those in Mexican Pacific waters (Escobar-Sánchez et al. 2011; Maz-Courrau et al. 2012) and in the Atlantic Ocean (Biton Porsmoguer et al. 2018) for blue sharks (P. glauca). For bathyal sharks, $\mathrm{Hg}$ concentrations reported in spurdogs (Squalus spp.) were similar to those reported in Australia (Pethybridge et al. 2010), but lower than those reported in Brazilian waters (de Pinho et al. 2002).

In our study, sharks from bathyal and open ocean habitats appear to have almost similar $\mathrm{Hg}$ concentrations while coastal elasmobranchs had the lowest $\mathrm{Hg}$ concentrations. Influence of habitat 
on $\mathrm{Hg}$ concentrations was reported in sharks (Chouvelon et al., 2012), teleosts (Monteiro et al. 1996; Chouvelon et al., 2018; Choy et al. 2009), cephalopods (Bustamante et al. 2006; Chouvelon et al. 2011), crustaceans (Chouvelon et al., 2012) and seabirds (Monteiro and Furness 1996), with higher $\mathrm{Hg}$ concentrations reported in organisms with deeper occurrence or foraging.

Differences in $\mathrm{Hg}$ concentrations between habitats may be explained by the species composition, size and trophic ecology in each habitat. Indeed, the low Hg levels of coastal elasmobranchs can be explained by the fact that most sampled coastal individuals are small sliteye sharks ( $L$. macrorhinus), which are small mesopredatory sharks (Cortés 1999; Jabado et al. 2015), followed by mostly juvenile scalloped hammerhead (S. lewini), which are generalist feeders targeting smaller prey than adults (Bush, 2003; Florez-Martínez et al. 2017). Such a diet composition is supported by lower $\delta^{15} \mathrm{~N}$ values in most coastal elasmobranchs. Conversely, the open ocean species we sampled included larger apex predators, which had bioaccumulated $\mathrm{Hg}$ to high levels and whose high $\delta^{15} \mathrm{~N}$ values may reflect a diet composed of large and high trophic level prey (Biton Porsmoguer et al. 2015; 2017; Camhi et al. 2008; Kiszka et al. 2015). However, $\mathrm{Hg}$ concentrations in bathyal sharks were almost similar to those of oceanic species despite the sampled bathyal shark species being smaller generalist feeders (Braccini et al. 2005; Ebert et al. 1992). Furthermore, the $\mathrm{Hg}$ concentrations in bathyal sharks are higher than in coastal species despite their similar trophic ecology and their smaller size. This is consistent with the observation of increasing $\mathrm{Hg}$ concentrations with depth in other taxa and in other locations (Chouvelon et al. 2012; Choy et al. 2009; Monteiro et al. 1996) and this indicates that other factors than the trophic ecology of the sampled species explain the differences of $\mathrm{Hg}$ concentrations in sharks between habitats. All bathyal species were sampled near La Réunion, a remote island with active volcanism likely to enrich surrounding waters in $\mathrm{Hg}$ (Chiffoleau et al. 2011). The geographical origin of these animals might therefore explain this pattern and this is supported by $\mathrm{Hg}$ analyses in coastal waters of La Réunion that reveals unexplained high $\mathrm{Hg}$ concentrations (Chiffoleau et al. 2011). Yet, coastal bull sharks ( $C$. 
leucas), which were sampled in La Réunion too, did not exhibit high Hg concentrations compared to both oceanic and bathyal species. Furthermore, the absence of relationship between $\mathrm{Hg}$ concentration and longitude in elasmobranchs from the open ocean also indicates that geographical origin is not a primary driver of mercury accumulation in elasmobranchs of the Indian Ocean. Consumption of prey in a restricted latitude range and high mobility may explain the absence of link between $\mathrm{Hg}$ concentration and geographical origin for oceanic elasmobranchs (Bird et al. 2018). $\mathrm{Hg}$ concentrations in bathyal sharks could also be explained by the $\mathrm{Hg}$ distribution in the water column. Increasing concentrations of $\mathrm{Hg}$ with depth were observed in the water column of various regions (Hammerschmidt and Bowman 2012; Horvat et al. 2003; Kim and Fitzgerald 1988), including in the southwestern Indian Ocean (Sunderland et al. 2011). In particular, a maximum level of highly bioavailable $\mathrm{CH}_{3} \mathrm{Hg}$ may be present in the mesopelagic environment ( $\mathrm{ca}$ 200-1000 m; Hammerschmidt and Bowman 2012; Horvat et al. 2003). This process is due to the higher net $\mathrm{CH}_{3} \mathrm{Hg}$ production below the mixed layer by microorganisms' activity than at the surface where a large portion of methylmercury is photodegraded (Blum et al. 2013). Consequently, considering that increasing levels of $\mathrm{CH}_{3} \mathrm{Hg}$ with depth were observed in southwestern Indian Ocean (Sunderland et al. 2011), that bathyal sharks rely on organic matter produced at the surface which is degraded and methylated while sinking (Bird et al. 2018; Blum et al. 2013) and that most of the $\mathrm{Hg}$ present in muscles of sharks is $\mathrm{CH}_{3} \mathrm{Hg}$ (Pethybridge et al. 2010; Storelli et al. 2003), similar $\mathrm{Hg}$ levels in open ocean and bathyal elasmobranchs despite differences of trophic positions are likely the result of higher bioavailability of $\mathrm{CH}_{3} \mathrm{Hg}$ in deep-sea waters as highlighted by higher proportions of $\mathrm{CH}_{3} \mathrm{Hg}$ relative to total $\mathrm{Hg}$ in deep-sea sharks (Pethybridge et al. 2010). Such a situation could also explain why bull sharks in coastal waters of La Réunion Island showed low $\mathrm{Hg}$ concentrations despite surface waters having high $\mathrm{Hg}$ concentrations (Chiffoleau et al. 2011), as the photodegradation of $\mathrm{CH}_{3} \mathrm{Hg}$ would make $\mathrm{Hg}$ less bioavailable. 
$\delta^{15} \mathrm{~N}$ values despite the small body size of this species. The maximum concentration of $\mathrm{CH}_{3} \mathrm{Hg}$ in the mesopelagic environment may explain the high $\mathrm{Hg}$ levels observed in P. kamoharai, which have a mesopelagic distribution (Compagno 1984a; Last and Stevens 1994), and high Hg concentrations previously reported in organisms foraging in the mesopelagic environment (Choy et al. 2009; Kojadinovic et al. 2007; Monteiro et al. 1996). Another hypothesis to explain this finding would be the existence of a longer food chain at smaller body sizes in the mesopelagic environment, as indicated by the high $\delta^{15} \mathrm{~N}$ values and estimated trophic position for this species and the higher rates of carnivory for mesopelagic zooplankton (Hannides et al. 2013). A third hypothesis would be that the high $\delta^{15} \mathrm{~N}$ values in $P$. kamoharai would be the result of higher $\delta^{15} \mathrm{~N}$ values in lower trophic positions and baseline sources of the mesopelagic food web where this species forages, as highlighted by increasing $\delta^{15} \mathrm{~N}$ values in suspended particles and zooplankton along depth (Hannides et al. 2013).

$\mathrm{Hg}$ concentrations consistently increased with fork length at the scales of the whole sampling area, of the habitats and of the species. This pattern has previously been documented in several species of sharks in different marine environments (Cresson et al. 2014; Hueter et al. 1995; Pethybridge et al. 2010; 2012; Rumbold et al. 2014). Body length may be used as a proxy of age in elasmobranchs (e.g. Cotton et al. 2011; Natanson et al. 2006; Pajuelo et al. 2011; Piercy et al. 2007; Skomal and Natanson 2003). Consequently, we may consider that increasing $\mathrm{Hg}$ concentrations with length results from ageing: because $\mathrm{Hg}$ is more efficiently assimilated than eliminated, it accumulates in the body with age. However, age alone may not explain this phenomenon, because the trophic level of organisms tends to increase with body length (Chouvelon et al. 2014; Hussey et al. 2011). Our results actually indicate that $\mathrm{Hg}$ concentrations and $\delta^{15} \mathrm{~N}$ values, and thus trophic level, are generally linked at the scale of the whole sampling area and within species. However, the link between $\mathrm{Hg}$ concentrations and $\delta^{15} \mathrm{~N}$ values appeared only in the bathyal habitat because there are still some species for which no relationship between $\mathrm{Hg}$ concentrations and $\delta^{15} \mathrm{~N}$ values occurred in the two other habitats. Nevertheless, large-scale variations of trophic level may explain regional 
differences of $\mathrm{Hg}$ concentrations. Indeed, higher $\mathrm{Hg}$ concentrations in South Africans C. leucas and S. lewini may be linked to higher trophic levels for these species in this region than in our study area (McKinney et al. 2016). In contrast, and in accordance with previous studies (e.g. Domi et al. 2005; Pethybridge et al. 2012; Rumbold et al. 2014), positive correlation between $\mathrm{Hg}$ concentrations and $\delta^{13} \mathrm{C}$ values are rarely found. This lack of relationship may suggest that all the sampled individuals in each species forage inside a single preferred habitat with no ontogenetic changes of feeding habitat or individual foraging specialisation or segregation (e.g. size or sexual segregation). By comparison, a relationship between $\mathrm{Hg}$ concentrations and $\delta^{13} \mathrm{C}$ values were observed in the wandering albatross Diodema exulans. This relationship results from the foraging segregation between males preying mainly in Antarctic waters and females preying in subtropical areas (Carravieri et al. 2014).

In conclusion, $\mathrm{Hg}$ concentrations in elasmobranchs living in three different types of habitat of the southwestern Indian Ocean appear to be linked to three factors: 1) trophic position, as shown by the relationship between $\mathrm{Hg}$ concentration and $\delta^{15} \mathrm{~N}$ values at the whole sample level, and by top predator sharks from the open ocean usually having higher $\mathrm{Hg}$ levels than the mesopredatory coastal elasmobranchs, 2) habitat, as shown by mesopredatory bathyal species having almost similar $\mathrm{Hg}$ concentrations as the top predator species of the open ocean despite their lower trophic position, 3) body size, as $\mathrm{Hg}$ concentrations increased with body length.

Many shark species are currently threatened by human activities (Clarke et al. 2006; Dulvy et al. 2014) and the $\mathrm{Hg}$ accumulation in their bodies could have additional detrimental effects on the dynamics of their populations (Depew et al. 2012; Sandheinrich and Wiener 2011). The results of the present study suggest that bathyal and oceanic sharks should be considered more carefully for human consumption. It is now well-established that the toxicity of $\mathrm{Hg}$ in teleost fish decreased when selenium (Se) concentrations are elevated (Kaneko and Ralston 2007; Ralston et al. 2008; 
Ralston and Raymond, 2010). However, the role of Se in commercial sharks could be minor, because its concentrations are usually not linked with $\mathrm{Hg}$ concentration, nor exceed it, particularly in oceanic blue and mako sharks (Domi et al. 2005; Escobar-Sánchez et al. 2011; Kaneko and Ralston 2007; Torres et al. 2017).

\section{Acknowledgements}

Our particular acknowledgements are due to sample collectors during longline fishing cruises and to IFREMER (IOSSS-Espadon project) and community data collectors and fishers (Blue Ventures) for providing shark samples. We are also very grateful to G. Guillou and P. Richard (University of La Rochelle, lab. LIENSs) for running the mass spectrometer analyses. We are grateful to the CPER (Contrat de Projet État-Région) and the FEDER (European Regional Development Fund). B. Le Bourg is a FNRS-FRIA fellow. The IUF (Institut Universitaire de France) is acknowledged for its support to P. Bustamante as a senior member. Sample collection and laboratory measurement of mercury and stable isotopes in some sharks from La Réunion Island were funded by the CHARC

project (EU FEDER/French Government/ La Réunion Island regional council). C. Trystram participated in the production of the data. We thank the anonymous referees for their helpful comments.

\section{References}

Adams, D.H., McMichael, R.H., 1998. Mercury levels in four species of sharks from the Atlantic coast of Florida. Fish. Bull. 97, 372-379.

Atwell, L., Hobson, K.A., Welch, H.E., 1998. Biomagnification and bioaccumulation of mercury in an arctic marine food web: insights from stable nitrogen isotope analysis. Can. J. Fish. Aquat. 
Sci. 55, 1114-1121. https://doi.org/10.1139/f98-001.

Bloom, N.S., 1992. On the chemical form of mercury in edible fish and marine invertebrate tissue.

Can. J. Fish. Aquat. Sci. 49, 1010-1017. https://doi.org/10.1139/f92-113.

Blum, J.D., Popp, B.N., Drazen, J.C., Choy, C.A., Johnson, M.W., 2013. Methylmercury production below the mixed layer in the North Pacific Ocean. Nat. Geosci. 6, 879-884. https://doi.org/10.1038/ngeo1918.

Biton Porsmoguer, S., Bănaru, D., Boudouresque, C.F., Dekeyser, I., Béarez, P., Miguez-Lozano, R., 2017. Compared diet of two pelagic shark species in the northeastern Atlantic Ocean. Vie Milieu 67, 21-25.

Biton Porsmoguer, S., Bănaru, D., Boudouresque, C.F., Dekeyser, I., Bouchoucha, M., MarcoMiraller, F., Lebreton, B., Guillou, G., Harmelin-Vivien, M., 2018. Mercury in blue shark (Prionace glauca) and shortfin mako (Isurus oxyrinchus) from north-eastern Atlantic: implication for fishery management. Mar. Pollut. Bull. 127, 131-138. https://doi.org/10.1016/j.marpolbul.2017.12.006.

Biton Porsmoguer, S., Bănaru, D., Boudouresque, C.F., Dekeyser, I., Viricel, A., Merchán, M., 2015. DNA evidence of the consumption of short-beaked common dolphin Delphinus delphis by the shortfin mako shark Isurus oxyrinchus. Mar. Ecol. Prog. Ser. 532, 177-183. https://doi.org/10.3354/meps11327.

Binohlan, C., Froese, R., Pauly, D., Reyes, R. 2011. The LENGTH-LENGTH table in FishBase. In: Froese, R., Pauly, R. (Eds.). FishBase. World Wide Web electronic publication, www.fishbase.org, version (04/2011).

Bird, C.S., Veríssimo, A., Magozzi, S., Abrantes, K.G., Aguilar, A., Al-Reasi, H., Barnett, A., Bethea, D.M., Biais, G., Borrel, A., Bouchoucha, M., Boyle, M., Brooks, E.J., Brunnschweiler, J., Bustamante, P., Carlisle, A., Catarino, D., Caut, S., Cherel, Y., Chouvelon, T., Churchill, D., Ciancio, J., Claes, J., Colaço, A., Courtney, D.L., Cresson, P., Daly, R., de 
Necker, L., Endo, T., Figueiredo, I., Frisch, A.J., Hansen, J.H., Heithaus, M., Hussey, N.E., Litembu, J., Juanes, F., Kinney, M.J., Kiszka, J.J., Klarian, S.A., Kopp, D., Leaf, R., Li, Y., Lorrain, A., Madigan, D.J., Maljković, A., Malpica-Cruz, L., Matich, P., Meekan, M.G., Ménard, F., Menezes, G.M., Munroe, S.E.M., Newman, M.C., Papastamatiou, Y.P., Pethybridge, H., Plumlee, J.D., Polo-Silva, C., Quaeck-Davis, K., Raoult, V., Reum, J., Torres-Rojas M.D., Teffer, A.K., Tilley, A., Valls, M., Vaudo, J.J., Wai, T.C., Wells, R.J.D., Wyatt, A.S.J., Yool, A., Trueman, C.N., 2018. A global perspective on the trophic geography of sharks. Nat. Ecol. Evol. 2, 299-305. https://doi.org/10.1038/s41559-017-0432-z.

Braccini, J.M., Gillanders, B.M., Walker, T.I., 2005. Sources of variation in the feeding ecology of the piked spurdog (Squalus megalops): implications for inferring predatoreprey interactions from overall dietary composition. ICES J. Mar. Sci. 62, 1076-1094. https://doi.org/10.1016/j.icesjms.2005.04.004.

Bush, A., 2003. Diet and diel feeding periodicity of juvenile scalloped hammerhead sharks, Sphyrna lewini, in Kāne'ohe Bay, Ō'ahu, Hawai'i. Environ. Biol. Fish 67, 1-11. https://doi.org/10.1023/A:102443870.

Bustamante, P., Lahaye, V., Durnez, C., Churlaud C., Caurant, F., 2006. Total and organic Hg concentrations in cephalopods from the North East Atlantic waters: influence of geographical origin and feeding ecology. Sci. Total Env. 368, 585-596. https://doi.org/10.1016/j.scitotenv.2006.01.038.

Camhi, M.D., Pikitch, E.K., Babcock, E.A., 2008. Sharks of the open ocean: biology, fisheries and conservation. Blackwell Publishing, Oxford, UK. https://doi.org/10.1002/9781444302516.

Campbell, L., Verburg, P., Dixon, D.G., Hecky, R.E., 2008. Mercury biomagnification in the food web of Lake Tanganyika (Tanzania, East Africa). Sci. Total Env. 402, 184-191. https://doi.org/10.1016/j.scitotenv.2008.04.017.

Carravieri, A., Bustamante, P., Tartu, S., Meillère, A., Labadie, P., Budzinski, H., Peluhet, L., Barbraud, C., Weimerskirch, H., Chastel, O., Cherel, Y., 2014. Wandering albatrosses 
document latitudinal variations in the transfer of persistent organic pollutants and mercury to Southern Ocean predators. Environ. Sci. Technol. 48, 14746-14755.

https://doi.org/10.1021/es504601m.

Chiffoleau, J.F., Auger, D., Averty, B., Bocquené, G., Rozuel, E., 2011. Evaluation des valeurs de bruits de fond dans l'eau de mer des 4 métaux de l'état chimique DCE. Cas des Départements d'Outre-Mer.

Chouvelon, T., Brach-Papa, C., Auger, D., Bodin, N., Bruzac, S., Crochet, S., Degroote, M., Hollanda, S.J., Hubert, C., Knoery, J., Munschy, C., Puech, A., Rozuel, E., Thomas, B., West, W., Bourjea, J., Nikolic, N., 2017. Chemical contaminants (trace metals, persistent organic pollutants) in albacore tuna from western Indian and south-eastern Atlantic Oceans: trophic influence and potential as tracers of populations. Sci. Total Env. 596-597, 481-495. https://doi.org/10.1016/j.scitotenv.2017.04.048.

Chouvelon, T., Caurent, F., Cherel, Y., Simon-Bouhet, B., Spitz, J., Bustamante, P., 2014. Speciesand size-related patterns in stable isotopes and mercury concentrations in fish help refine marine ecosystem indicators and provide evidence for distinct management units for hake in the Northeast Atlantic. ICES J. Mar. Sci. 71, 1073-1087. https://doi.org/10.1093/icesjms/fst199.

Chouvelon, T., Cresson, P., Bouchoucha, M., Brach-Papa, C., Bustamante, P., Crochet, S., MarcoMiralles, F., Thomas, B., Knoery, J., 2018. Oligotrophy as a major driver of mercury bioaccumulation in medium-to high-trophic level consumers: a marine ecosystemcomparative study. Environ. Pollut. 233, 844-854. https://doi.org/10.1016/j.envpol.2017.11.015.

Chouvelon, T., Spitz, J., Caurent, F., Mèndez-Fernandez, P., Autier, J., Lassus-Débat, A., Chappuis, A., Bustamante, P., 2012. Enhanced bioaccumulation of mercury in deep-sea fauna from the Bay of Biscay (north-east Atlantic) in relation to trophic positions identified by analysis of carbon and nitrogen stable isotopes. Deep-Sea Res. 165, 113-124 
https://doi.org/10.1016/j.dsr.2012.02.010.

Chouvelon, T., Spitz, J., Cherel, Y., Caurant, F., Sirmel, R., Mèndez-Fernandez, P., Bustamante, P., 2011. Interspecific and ontogenic differences in $\delta^{13} \mathrm{C}$ and $\delta^{15} \mathrm{~N}$ values and $\mathrm{Hg}$ and $\mathrm{Cd}$ concentrations of cephalopods. Mar. Ecol. Prog. Ser. 433, 107-120. https://doi.org/10.3354/meps09159.

Choy, C.A., Popp, B.N., Kaneko, J.J., Drazen, J.C., 2009. The influence of depth on mercury levels in pelagic fishes and their prey. Proc. Natl. Acad. Sci. USA 106, 13865-13869. https://doi.org/10.1073/pnas.0900711106.

Clarke, S.C., McAllister, M.K., Milner-Gulland, E.J., Kirkwood, G.P., Michielsens, C.G.J., Agnew, D.J., Pikitch, E.K., Nakano, H., Shivji, M.S., 2006. Global estimates of shark catches using trade records from commercial markets. Ecol. Lett. 9, 1115-1126. https://doi.org/10.1111/j.1461-0248.2006.00968.x.

Compagno, L.J.V., 1984a. Sharks of the world. An annotated and illustrated catalogue of shark species known to date. Part 1 - Hexanchiformes to Lamniformes. FAO Fish. Synop. 4, 1-249. Compagno, L.J.V., 1984b. Sharks of the world. An annotated and illustrated catalogue of shark species known to date. Part 2 - Carcharhiniformes. FAO Fish. Synop. 4, 251-655.

Cortés, E., 1999. Standardized diet compositions and trophic levels of sharks. ICES J. Mar. Sci. 56, 707-717. https://doi.org/10.1006/jmsc.1999.0489.

Cotton, C.F., Grubbs, R.D., Day-Engel, T.S., Lynch, P.D., Musick, J.A., 2011. Age, growth and reproduction of a common deep-water shark, shortspine spurdog (Squalus cf. mitsukurii), from Hawaiian waters. Mar. Freshwater Res. 62, 811-822. https://doi.org/10.1071/MF10307.

Cresson, P., Fabri, M.C., Bouchoucha, M., Brach Papa, C., Chavanon, F., Knoery, J., Miralles, F., Cossa, D., 2014. Mercury in organisms from the Northwestern Mediterranean slope: importance of food sources. Sci. Total Env. 497-498, 229-238. https://doi.org/10.1016/j.scitotenv.2014.07.069.

de Pinho, A.P., Guimarães, J.R.D., Martins, A.S., Costa, P.A.S., Olavo, G., Valentin, J., 2002. Total 
mercury in muscle tissue of five shark species from Brazilian offshore waters: effects of feeding habit, sex, and length. Enivron. Res. 89, 250-258.

https://doi.org/10.1006/enrs.2002.4365.

Depew, D.C., Basu, N., Burgess, N.M., Campbell, L.M., Devlin, E.W., Drevnick, P.E., Hammerschmidt, C.R., Murphy, C.A., Sandheinrich, M.B., Wiener, J.G., 2012. Toxicity of dietary methylmercury to fish: derivation of ecologically meaningful threshold concentrations. Environ. Toxicol. Chem. 31, 1536-1547. https://doi.org/10.1002/etc.1859.

Díez, S., 2008. Human Health Effects of Methylmercury Exposure. In: Whiteacre, D.M. (Ed.), Reviews of Environmental Contamination and Toxicology 198. Springer Science+Business Media, LLC, New York, USA, pp 111-132. https://doi.org/10.1007/978-0-387-09646-9.

Domi, N., Bouquegneau, J.M., Das, K., 2005. Feeding ecology of five commercial shark species of the Celtic Sea through stable isotope and trace metal analysis. Mar. Environ. Res. 60, 551569. https://doi.org/10.1016/j.marenvres.2005.03.001.

Dulvy, N.K., Fowler, S.L., Musick, J.A., Cavanagh, R.D., Kyne, P.M., Harrison, L.R., Carlson, J.K., Davidson, L.N.K., Fordham, S.V., Francis, M.P., Pollock, C.M., Simpfendorfer, C.A., Burgess, G.H., Carpenter, K.E., Compagno, L.J.V., Ebert, D.A., Gibson, C., Heupel, M.R., Livingstone, S.R., Sanciangco, J.C., Stevens, J.D., Valenti, S., White, W.T., 2014. Extinction risk and conservation of the world's sharks and rays. eLife 3, e00590. https://doi.org/10.7554/eLife.00590.

Ebert, D.A., Compagno, L.J.V., Cowley, P.D., 1992. A preliminary investigation of the feeding ecology of squaloid sharks off the west coast of southern Africa. S. Afr. J. Mar. Sci. 12, 601609. https://doi.org/10.2989/02577619209504727.

Escobar-Sánchez, O., Galván-Magaña, F., Rosíles-Martínez, R., 2011. Biomagnification of mercury and selenium in blue shark Prionace glauca from the Pacific Ocean off Mexico. Biol. Trace Elem. Res. 144, 550-559. https://doi.org/10.1007/s12011-011-9040-y.

Fitzgerald, W.F., Lamborg, C.H., Hammerschmidt, C.R., 2007. Marine biogeochemical cycling of 
mercury. Chem. Rev. 107, 641-662. https://doi.org/10.1021/cr050353m.

Florez-Martínez, I.A., Torres-Rojas, Y.E., Galván-Magaña, F., Ramos-Miranda, J., 2017. Diet comparison between silky sharks (Carcharhinus falciformis) and scalloped hammerhead sharks (Sphyrna lewini) off the south-west coast of Mexico. J. Mar. Biol. Assoc. UK. 97, 337345. https://doi.org/10.1017/S0025315416000424.

Hammerschmidt, C.R., Bowman, K.L., 2012. Vertical methylmercury distribution in the subtropical North Pacific Ocean. Mar. Chem. 132-133, 77-82. https://doi.org/10.1016/j.marchem.2012.02.005.

Hannides, C.C.S., Popp, B.N., Choy, C.A., Drazen, J.C., 2013. Midwater zooplankton and suspended particle dynamics in the North Pacific Subtropical Gyre: A stable isotope perspective. Limnol. Oceanogr. 58, 1931-1946. https://doi.org/10.4319/lo.2013.58.6.1931.

Hisamichi, Y., Haraguchi, K., Endo, T., 2010. Levels of mercury and organochlorine compounds and stable isotope ratios in three tuna species taken from different regions of Japan. Environ. Sci. Technol. 44, 5971-5978. https://doi.org/10.1021/es1008856.

Horvat, M., Kotnik, J., Logar, M., Fajon, V., Zvonarić, T., Pirrone, N., 2003. Speciation of mercury in surface and deep-sea waters in the Mediterranean Sea. Atmos. Environ. 37 (S1), S93-S108. https://doi.org/10.1016/S1352-2310(03)00249-8.

Hobson, K.A., 1999. Tracing origins and migration of wildlife using stable isotopes: a review. Oecologia 120, 314-326. https://doi.org/10.1007/s004420050865.

Hueter, R.E., Fong, W.G., Henderson, G., French, M.F., Manire, C.A., 1995. Methylmercury concentration in shark muscle by species, size and distribution of sharks in Florida coastal waters. Water Air Soil Poll. 80, 893-899. https://doi.org/10.1007/BF01189741.

Humber, F., Andriamahaino, E.T., Beriziny, T., Botosoamananto, R., Godley, B.J., Gough, C., Pedron, S., Ramahery, V., Broderick, A.C., 2017. Assessing the small-scale shark fishery of Madagascar through community-based monitoring and knowledge. Fish. Res. 186, 131-143. https://doi.org/10.1016/j.fishres.2016.08.012. 
Hussey, N.E., Dudley, S.F.J., McCarthy, I.D., Cliff, G., Fisk, A.T., 2011. Stable isotope profiles of large marine predators: viable indicators of trophic position, diet, and movement in sharks? Can. J. Fish. Aquat. Sci. 68, 2029-2045. https://doi.org/10.1139/2011-115.

Hussey, N.E., MacNeil, M.A., McMeans, B.C., Olin, J.A., Dudley, S.F.J., Cliff, G., Wintner, S.P., Fennessy, S.T., Fisk, A.T., 2014a. Rescaling the trophic structure of marine food webs. Ecol. Lett. 17, 239-250. https://doi.org/10.1111/ele.12226.

Hussey, N.E., MacNeil, M.A., McMeans, B.C., Olin, J.A., Dudley, S.F.J., Cliff, G., Wintner, S.P., Fennessy, S.T., Fisk, A.T., 2014b. Corrigendum to Hussey et al. (2014). Ecol. Lett. 17, 768. https://doi.org/10.1111/ele.12270.

Hussey, N.E., MacNeil, M.A., Olin, J.A., McMeans, B.C., Kinney, M.J., Chapman, D.D., Fisk, A.T., 2012. Stable isotopes and elasmobranchs: tissue types, methods, applications and assumptions. J. Fish Biol. 80, 1449-1484. https://doi.org/10.1111/j.1095-8649.2012.03251.x.

Jabado, R.W., Al Ghais, S.M., Hamza, W., Henderson, A.C., Al Mesafri, A.A., 2015. Diet of two commercially important shark species in the United Arab Emirates: milk shark, Rhizoprionodon acutus (Rüppell, 1837), and slit-eye shark, Loxodon macrorhinus (Müller \& Henle, 1839). J. Appl. Ichthyol. 31, 870-875. https://doi.org/10.1111/jai.12805.

Jones, H.J., Butler, E.C.V., Macleod, C.K., 2013. Spatial variability in selenium and mercury interactions in a key recreational fish species: implications for human health and environmental monitoring. Mar. Pollut. Bull. 74, 231-236. https://doi.org/10.1016/j.marpolbul.2013.06.052.

Kaneko, J.J., Ralston, N.V.C., 2007. Selenium and mercury in pelagic fish in the Central North Pacific near Hawaii. Biol. Trace Elem. Res. 119, 242-254. https://doi.org/10.1007/s12011007-8004-8.

Kim, J., Fitzgerald, W., 1988. Gaseous mercury profiles in the tropical Pacific Ocean. Geophys. Res. Lett. 15, 40-43. https://doi.org/10.1029/GL015i001p00040.

Kiszka, J.J., Aubail, A., Hussey, N.E., Heithaus, M.R., Caurent, F., Bustamante, P., 2015. Plasticity 
of trophic interactions among sharks from the oceanic south-western Indian Ocean revealed by stable isotope and mercury analyses. Deep-Sea Res. Pt. 1 96, 49-58. https://doi.org/10.1016/j.dsr.2014.11.006.

Kiszka, J.J., Charlot, K., Hussey, N.E., Heithaus, M.R., Simon-Bouhet, B., Humber, F., Caurent, F., Bustamante, P., 2014. Trophic ecology of common elasmobranchs exploited by artisanal shark fisheries off south-western Madagascar. Aquat. Biol. 23, 29-38. https://doi.org/10.3354/ab00602.

Kiszka, J.J., Heithaus, M.R., 2014. The state of knowledge on sharks for conservation and management. In: Techera, E.J., Klein, N. (Eds.), Sharks: Conservation, Governance and Management. Earthscan, USA, pp 69-88.

Kohler, N.E., Casey, J.G., Turner, P.A., 1996.Length-length and length-weight relationships for 13 shark species from the Western North Atlantic. NOAA Technical Memorandum NMFS-NE110.

Kojadinovic, J., Potier, M., Le Corre, M., Cosson, R.P., Bustamante, P., 2006. Mercury content in commercial pelagic fish and its risk assessment in the Western Indian Ocean. Sci. Total Env. 366, 688-700. https://doi.org/10.1016/j.scitotenv.2006.02.006.

Kojadinovic, J., Potier, M., Le Corre, M., Cosson, R.P., Bustamante, P., 2007. Bioaccumulation of trace elements in pelagic fish from the Western Indian Ocean. Environ. Pollut. 146, 548-566. https://doi.org/10.1016/j.envpol.2006.07.015.

Kousteni, V., Megalofonou, P., Dassenakis, M., Stathopoulou, E., 2006. Total mercury concentrations in edible tissues of two elasmobranch species from Crete (eastern Mediterranean Sea). Cybium 30, 119-123.

Last, P.R., Stevens, J.D., 1994. Sharks and rays of Australia. Hobart, CSIRO Australia. Lavoie, R.A., Hebert, C.E., Rail, J.F., Braume, B.M., Yumvihoze, E., Hill, L.G., Lean, D.R.S., 2010. Trophic structure and mercury distribution in a Gulf of St. Lawrence (Canada) food web using stable isotope analysis. Sci. Total Env. 408, 5522-5539. 
https://doi.org/10.1016/j.scitotenv.2010.07.053.

Le Bourg, B., Kiszka, J., Bustamante, P., 2014. Mother-embryo isotope $\left(\delta^{15} \mathrm{~N}, \delta^{13} \mathrm{C}\right)$ fractionation and mercury $(\mathrm{Hg})$ transfer in aplacental deep-sea sharks. J. Fish Biol. 84, 1574-1581. https://doi.org/10.1111/jfb.12357.

Lyons, K., Lowe, C., 2013. Mechanisms of maternal transfer of organochlorine contaminants and mercury in the common thresher shark (Alopias vulpinus). Can. J. Fish. Aquat. Sci. 70, 16671672. https://doi.org/10.1139/cjfas-2013-0222.

Mason, R.P., Reinfelder, J.R., Morel, F.M.M., 1995. Bioaccumulation of Mercury and methylmercury. Water Air Soil Poll. 80, 915-921. https://doi.org/10.1007/BF01189744.

Maz-Courrau, A., López-Vera, C., Galván-Magaña, F., Escobar-Sánchez, O., Rosíles-Martínez, R., Sanjuán-Muñoz, A., 2012. Bioaccumulation and biomagnification of total mercury in four exploited shark species in the Baja California Peninsula, Mexico. Bull. Environ. Contam. Toxicol. 88, 129-134. https://doi.org/10.1007/s00128-011-0499-1.

McKinney, M.A., Dean, K., Hussey, N.E., Cliff, G., Wintner, S.P., Dudley, S.F.J., Zungu, M.P., Fisk, A., 2016. Global versus local causes and health implications of high mercury concentrations in sharks from the east coast of South Africa. Sci. Total Env. 541, 176-183. https://doi.org/10.1016/j.scitotenv.2015.09.074.

Michener, R.H., Kaufman, L., 2007. Stable isotopes ratios as tracers in marine food webs: an update. In: Michener, R., Lajtha, K. (Eds.), Stable isotopes in ecology and environmental science. Blackwell Publishing, Malden, USA, pp 238-282.

Monteiro, L.R., Costa, V., Furness, R.W., Santos, R.S., 1996. Mercury concentrations in prey fish indicate enhanced bioaccumulation in mesopelagic environments. Mar. Ecol. Prog. Ser. 141, 21-25. https://doi.org/10.3354/meps141021.

Natanson, L.J., Kohler, N.E., Ardizzone, D., Caillet, G.M., Wintner, S.P., Mollet, H.F., 2006. Validated age and growth estimates for the shortfin mako, Isurus oxyrinchus, in the North Atlantic Ocean. Environ. Biol. Fish 77, 367-383. https://doi.org/10.1007/s10641-006-9127-z. 
Pajuelo, J.G., Garciá, S., Lorenzo, J.M., González, J.A., 2011. Population biology of the shark, Squalus megalops, harvested in the central-east Atlantic Ocean. Fish. Res. 108, 31-41. https://doi.org/10.1016/j.fishres.2010.11.018.

Pethybridge, H., Butler, E.C.V., Cossa, D., Daley, R., Boudou, A. 2012. Trophic structure and biomagnification of mercury in an assemblage of deepwater chondrichthyans from southeastern Australia. Mar. Ecol. Prog. Ser. 451, 163-174. https://doi.org/10.3354/meps09593.

Pethybridge, H., Cossa, D., Butler, E.C.V., 2010. Mercury in 16 demersal sharks from southeast Australia: biotic and abiotic sources of variation and consumer health implications. Mar. Environ. Res. 69, 18-26. https://doi.org/10.1016/j.marenvres.2009.07.006.

Piercy, A.N., Carlson, J.K., Sulikowski, J.A., Burgess, G.H., 2007. Age and growth of the scalloped hammerhead shark, Sphyrna lewini, in the north-west Atlantic Ocean and Gulf of Mexico. Mar. Freshwater Res. 58, 34-40. https://doi.org/10.1071/MF05195.

Power, M., Klein, G.M., Guiguer, K.R.R.A., Kwan, M.K.H., 2002. Mercury accumulation in the fish community of a sub-Arctic lake in relation to trophic position and carbon sources. J. Appl. Ecol. 39, 819-830. https://doi.org/10.1046/j.1365-2664.2002.00758.x.

Ralston, N.V.C., Ralston, C.R., Blackwell III, J.L., Raymond, L.J., 2008. Dietary and tissue selenium in relation to methylmercury toxicity. NeuroToxicology 29, 802-811. https://doi.org/10.1016/j.neuro.2008.07.007.

Ralston, N.V.C., Raymond, L.J., 2010. Dietary selenium's protective effects against methylmercury toxicity. Toxicology 278, 112-123. https://doi.org/10.1016/j.tox.2010.06.004.

Rice, W.R., 1989. Analyzing tables of statistical tests. Evolution 43, 223-225.

Rumbold, D., Wasno, R., Hammerschlag, N., Volety, A., 2014. Mercury accumulation in sharks from the coastal waters of southwest Florida. Arch. Environ. Contam. Toxicol. 67, 402-412. https://doi.org/10.1007/s00244-014-0050-6. 
Sackett, D.K., Cope, W.G., Rice, J.A., Aday, D.D., 2013. The influence of fish length on tissue mercury dynamics: implications for natural resource management and human health risk. Int. J. Environ. Res. Public Health 10, 638-659. https://doi.org/10.3390/ijerph10020638.

Sandheinrich, M.B., Wiener, J.G., 2011. Methylmercury in freshwater fish-Recent advances in assessing toxicity of environmentally relevant exposures. In: Beyer, W.N., Meador, J.P. (Eds.), Environmental Contaminants in Biota: Interpreting Tissue Concentrations, 2nd ed. CRC/Taylor and Francis, Boca Raton, FL, USA, pp 169-190.

Selin, N.E., 2009. Global biogeochemical cycling of mercury: a review. Annu. Rev. Environ. Resour. 34, 43-63. https://doi.org/10.1146/annurev.environ.051308.084314.

Skomal, G.B., Natanson, L.J., 2003. Age and growth of the blue shark (Prionace glauca) in the North Atlantic Ocean. Fish. Bull. 101, 627-639.

Storelli, M.M., Ceci, E., Storelli, A., Marcotrigiano, G.O., 2003. Polychlorinated biphenyl, heavy metal and methylmercury residues in hammerhead sharks: contaminant status and assessment. Mar. Pollut. Bull. 46, 1035-1039. https://doi.org/10.1016/S0025-326X(03)00119-X.

Storelli, M.M., Giacominelli-Stuffler, R., Marcotrigiano, G.O., 2002. Total and methylmercury residues in cartilaginous fish from Mediterranean Sea. Mar. Pollut. Bull. 44, 1354-1358. https://doi.org/10.1016/S0025-326X(02)00223-0.

Sunderland, E.M., Krabbenhoft, D.P., Corbitt, E.S., Landing, W.M., 2011. Distributions of mercury and methylmercury in the Indian Ocean. Presentation at the 10th International Conference on Mercury as a Global Pollutant, Halifax, Canada, 2011. 